\title{
Mouse islet cell lysis mediated by interleukin-1-induced Fas
}

\author{
K. Yamada, N. Takane-Gyotoku, X. Yuan, F. Ichikawa, C. Inada, K. Nonaka \\ Division of Endocrinology and Metabolism, Department of Medicine, Kurume University School of Medicine, Kurume, Japan
}

\begin{abstract}
Summary This study was conducted to investigate the possible involvement of Fas in $\beta$-cell death in insulitis of Type 1 (insulin-dependent) diabetes mellitus. Although primary cultured Balb/c mouse islet cells did not express Fas mRNA, 4-12 hours of treatment with $10^{2}-10^{5} \mathrm{U} / \mathrm{l}$ of mouse interleukin- $1 \alpha$ (IL-1 $\alpha$ ) induced the expression of Fas mRNA. Surface Fas expression was detected by immunofluorescence flow cytometry using a non-cytolytic anti-Fas monoclonal antibody after 6 or $12 \mathrm{~h}$ of incubation with $10^{3} \mathrm{U} / \mathrm{l}$ of IL- $1 \alpha$. Primary islet cells were resistant to an agonistic anti-Fas monoclonal antibody. However, $12 \mathrm{~h}$ pretreatment with IL-1 $\alpha$ sensitized islet cells to its cytolytic effect. Significant cell death was observed $24 \mathrm{~h}$ after the addition of anti-Fas, and progressively increased until $72 \mathrm{~h}$, when specific ${ }^{51} \mathrm{Cr}$ release was $72 \pm 6 \%$. Agarose gel electrophoresis of DNA extracted from cells
\end{abstract}

exposed to IL- $1 \alpha$ and agonistic anti-Fas showed internucleosomal DNA fragmentation, a hallmark of apoptotic cell death. Since the Fas antibody showed no cross-reactive activity of tumour necrosis factor (TNF), the cytotoxic effect was not mediated by TNF receptors. A protein synthesis inhibitor cycloheximide augmented Fas-mediated islet cell death. The Fas-mediated killing of islet cells was not L-argininedependent, or blocked by $\mathrm{N}^{\mathrm{G}}$-monomethyl-L-arginine. $\beta$-TC1 cells also expressed Fas mRNA when exposed to IL- $1 \alpha$ or IL- $1 \alpha$ plus interferon- $\gamma$. These observations suggest that Fas-mediated apoptosis may be a mechanism of islet cell death in autoimmune insulitis. [Diabetologia (1996) 39: 1306-1312]

Keywords Islets of Langerhans, Fas, CD95, apoptosis, interleukin-1, interferon- $\gamma$, DNA cleavage.
A bulk of evidence indicates that $\beta$-cell destruction in type 1 (insulin-dependent) diabetes mellitus results from cell-mediated autoimmunity. Pancreatic infiltrates of human type 1 diabetes $[1,2]$ and rodent models $[3,4]$ include $\mathrm{CD}^{+}{ }^{+}$and $\mathrm{CD}^{+}{ }^{+} \mathrm{T}$ lymphocytes, B lymphocytes, natural killer cells, and

\section{Received: 5 April 1996 and in revised form: 7 August 1996}

Corresponding author: Dr. K. Yamada, Division of Endocrinology and Metabolism, Department of Medicine, Kurume University School of Medicine, Asahimachi, Kurume, 830 Japan

Abbreviations: IL-1, Interleukin-1; TNF; tumour necrosis factor; IFN, interferon; FasL, Fas ligand; CTL, cytotoxic T-lymphocyte; RT-PCR, reverse transcription polymerase chain reaction; FITC, fluorescein isothiocyanate; NO, nitric oxide; NMMA, $\mathrm{N}^{\mathrm{G}}$-monomethyl-L-arginine; MHC, major histocompatibility complex. macrophages. It is known that a part of T-cell-mediated cytotoxicity is $\mathrm{Ca}^{2+}$-independent $[5,6]$, whereas a well-known perforin/granzyme-based mechanism is $\mathrm{Ca}^{2+}$-dependent. Recently, it was shown that the former is mediated by Fas (APO-1, CD95). Fas is a cell-surface receptor belonging to nerve growth factor/tumour necrosis factor (TNF) receptor superfamily $[7,8]$. The Fas-mediated death mechanism plays an important regulatory role in autoimmune disorders of $l p r$ mice $[9,10]$ and gld mice $[11,12]$. Fas ligand (FasL) identified in activated T-cell lines has significant homology with TNF- $\alpha$ and TNF- $\beta[13,14]$. Engagement of FasL and Fas on target cells results in the activation of an intrinsic suicide programme in target cells leading to apoptotic cell death. Fas-FasL interaction is involved in the cytotoxic action of $\mathrm{CD}^{+}{ }^{+}$cytotoxic $\mathrm{T}$ lymphocytes (CTLs) and, to a lesser extent, in that of CD8 ${ }^{+}$CTLs [15-17]. Fas is also 
involved in the cytotoxic activity of natural killer cells $[18,19]$. Several organs including thymus and liver constitutively express Fas [20]. If islet cells express Fas in autoimmune insulitis, the cells could be killed not only by the perforin/granzyme-based mechanism but also by the Fas-mediated mechanism. In this study we examined the possible effect of interleukin1 (IL-1) on Fas expression and Fas-mediated death of mouse islet cells.

\section{Materials and methods}

Islet cells, cytokines and antibodies. Pancreatic islets were isolated by collagenase digestion of pancreases from 10-weekold male Balb/c mice, and purified by Percoll gradient and hand picking to eliminate exocrine cells. Islets were incubated with $1 \mathrm{mmol} / \mathrm{l}$ glycoletherdiaminetetra acetic acid for $10 \mathrm{~min}$, and dispersed with $2 \mathrm{~g} / \mathrm{l}$ collagenase type IV (Worthington, Freehold, N.J., USA) and $10^{5}$ U/1 DNase (Sigma, St. Louis, M.O., USA). After adherent nonendocrine cells were removed, endocrine cells were cultured in RPMI-1640 supplemented with $10 \%$ heat-inactivated fetal bovine serum. $\beta$-TC1, a $\beta$-cell line derived from a transgenic mouse with insulin-promoted SV40 large T antigen [21], was also maintained in the culture medium. Recombinant mouse IL-1 $\alpha\left(8 \times 10^{6} \mathrm{U} / \mathrm{mg}\right)$ and recombinant mouse interferon- $\gamma($ IFN- $\gamma)\left(1 \times 10^{7} \mathrm{U} / \mathrm{mg}\right)$ were purchased from Genzyme (Cambridge, Mass., USA). Cytolytic hamster anti-mouse Fas monoclonal antibody (clone RK8) and non-cytolytic rat anti-mouse Fas monoclonal antibodies (clone RMF6) were provided by MBL (Nagoya, Japan).

Reverse transcription polymerase chain reaction (RT-PCR) of Fas $m R N A$. Islet cells were cultured at the density of $5 \times 10^{4}$ cells/well for 2 days, followed by 1-12 h exposure to IL- $1 \alpha$ at the concentrations of $10^{2}-10^{5} \mathrm{U} / \mathrm{l}$. $\beta$-TC1 cells inoculated at a density of $10^{5}$ cells/well in 24-well trays were cultured for $24 \mathrm{~h}$ and exposed to IL- $1 \alpha$ and/or IFN- $\gamma$ for $6 \mathrm{~h}$. RNA was extracted by the single-step method using RNAzol B (Biotecx, Houston, Texas, USA), and $200 \mathrm{ng}$ of total RNA was reverse transcribed with $100 \mathrm{U}$ of $\mathrm{RNase} \mathrm{H}^{-}$Moloney murine leukaemia virus reverse transcriptase (Gibco BRL, Grand Island, N.Y., USA) for $60 \mathrm{~min}$ at $37^{\circ} \mathrm{C}$ and for $30 \mathrm{~min}$ at $42^{\circ} \mathrm{C}$. After completion of the reaction, the reverse transcriptase was inactivated at $94^{\circ} \mathrm{C}$ for 3 min. Amplification of mouse Fas cDNA was performed by PCR with $5 \times 10^{4} \mathrm{U} / 1$ of Taq DNA polymerase (Roche, Branchburg, N.J., USA) using a sense primer 5 '-ACAGTTAAGAGTTCATAC and an antisense primer $5^{\prime}$ GGTTGCTGTGCATGGCTC, resulting in a PCR product of 424 bp between bases 45 and 468 of the Fas coding region. Although the whole structure of mouse Fas gene has not been reported yet, at least one intron exists between the primer sites [10]. A cDNA sequence of $\beta$-actin was amplified as control with primers 5 '-ATCCGTAAAGACCTCTATGC (945-964) and $5^{\prime}$-AACGCAGCTCAGTAACAGTC (1212-1231). A thermal cycle was $1 \mathrm{~min} 20 \mathrm{~s}$ at $94^{\circ} \mathrm{C}, 1 \mathrm{~min}$ at $55^{\circ} \mathrm{C}$ and $2 \mathrm{~min}$ at $72^{\circ} \mathrm{C}$. The Fas and $\beta$-actin sequences were amplified by 35 and 30 cycles, respectively. Aliquots of $10 \mu \mathrm{l}$ from each reaction were analysed by electrophoresis together with $1 \mathrm{~kb}$ DNA ladder (Gibco BRL) in $2.5 \%$ agarose gel and stained with ethidium bromide. The PCR products of Fas were ligated into the pCR vector of the TA cloning kit (Invitrogen, Leek, The Netherlands). Competent cells were transformed according to the manufacture's instructions. DNA from positive clones were extracted using the QIAprep plasmid kit (QIAGEN, Hilden,
Germany), and sequenced bidirectionally using the Cy5 AutoRead sequencing kit (Pharmacia Biotech, Uppsala, Sweden).

Flow cytometric analysis of Fas expression. After 2-day primary culture, dispersed islet cells at a density of $2 \times 10^{5}$ cells/ well were exposed to $10^{3} \mathrm{U} / \mathrm{l}$ of mouse IL-1 $\alpha$ for 6 or $12 \mathrm{~h}$. Islet cells resuspended with trypsin/EDTA were incubated in $100 \mu \mathrm{l}$ of RPMI-1640 containing 1\% bovine serum albumin and $10 \mathrm{mg} / \mathrm{l}$ non-cytolytic anti-Fas monoclonal antibody (RMF6) or rat IgG (Jackson Immunoresearch, West Grove, Pa., USA) for $2 \mathrm{~h}$ at $4^{\circ} \mathrm{C}$, and washed twice with cold RPMI-1640. Cells were then incubated with fluorescein isothiocyanate (FITC) conjugated rabbit anti-rat Ig (Dako, Glostrup, Denmark) for $30 \mathrm{~min}$ at $4^{\circ} \mathrm{C}$. After washing fluorescence intensity was analysed by flow cytometry (Ortho, Tokyo, Japan).

${ }^{51} \mathrm{Cr}$ release assay. Islet cell microcultures $\left(2 \times 10^{4}\right.$ cells/well $)$ were incubated with $4 \mu \mathrm{Ci}{ }^{51} \mathrm{Cr}$ sodium chromate (New England Nuclear, Boston, Mass., USA) in $100 \mu$ l complete medium for $2 \mathrm{~h}$ at $37^{\circ} \mathrm{C}$, and washed four times with warm RPMI-1640 medium. After 4-h reincubation in ${ }^{51} \mathrm{Cr}$-free complete medium at $37^{\circ} \mathrm{C}$, cells were washed twice with the medium, and refed with $100 \mu \mathrm{l} /$ well of complete medium containing $10^{3} \mathrm{U} / \mathrm{l}$ of IL-1 $\alpha$. After $12 \mathrm{~h}$, anti-Fas monoclonal antibody (RK8) was added to cultures at a concentration of $5 \mathrm{mg} / \mathrm{l}$. Aliquots from each reaction mixture were counted in a gamma counter. Total ${ }^{51} \mathrm{Cr}$ release was determined by the addition of $2 \%$ Triton-X100, and specific ${ }^{51} \mathrm{Cr}$ release was calculated by the formula of $100 \times($ test $\mathrm{cpm}-$ spontaneous $\mathrm{cpm}) /($ total $\mathrm{cpm}$ - spontaneous cpm).

Determination of nucleosomal DNA cleavage. After 2-day primary culture, $3 \times 10^{5}$ dispersed mouse islet cells were incubated with $10^{3} \mathrm{U} / 1$ of IL-1 $\alpha$ for $12 \mathrm{~h}$ and then exposed to $5 \mathrm{mg}$ / 1 of agonistic anti-Fas monoclonal antibody (RK8) for $48 \mathrm{~h}$. Cells were washed twice with RPMI-1640, precipitated by centrifugation, and incubated in $100 \mu \mathrm{l}$ of lysis solution containing $50 \mu \mathrm{g}$ proteinase K (Sigma), $50 \mu \mathrm{g}$ RNase A (Sigma), and $1 \mu \mathrm{g}$ sodium dodecyl sulphate at $37^{\circ} \mathrm{C}$ for $30 \mathrm{~min}$. The lysates were added with $150 \mu \mathrm{l}$ of $\mathrm{NaI}$ solution containing $6 \mathrm{~mol} / \mathrm{l} \mathrm{NaI}$, $13 \mathrm{mmol} / 1$ EDTA, $0.5 \%$ sodium-N-lauroyl sarcosinate, $1 \%$ glycogen, and $26 \mathrm{mmol} / \mathrm{l}$ Tris- $\mathrm{HCl} \mathrm{pH} \mathrm{8.0,} \mathrm{and} \mathrm{incubated} \mathrm{at}$ $60^{\circ} \mathrm{C}$ for $15 \mathrm{~min}$. DNA was precipitated with an equal volume of isopropanol, and washed with $50 \%$ and $100 \%$ isopropanol. DNA samples were analysed together with $1 \mathrm{~kb}$ DNA ladder (Gibco BRL) by electrophoresis on $2 \%$ agarose containing $0.4 \mathrm{mg} / \mathrm{l}$ of ethydium bromide.

TNF activity assay. TNF bioactivity was measured by the amido black method [22] using L929 cells as targets. Recombinant mouse TNF- $\alpha$ (Genzyme) or anti-Fas antibody was diluted in RPMI-1640 containing $1 \mathrm{mg} / \mathrm{l}$ of actinomycin $\mathrm{D}$, and added to L929 microcultures in 96-well culture plates. After 18-h incubation, the cells were fixed with $10 \%$ formalin in $0.1 \mathrm{~mol} / \mathrm{l} \mathrm{so-}$ dium acetate $/ 9 \%$ acetic acid, stained with $0.05 \%$ amido black in $0.1 \mathrm{~mol} / 1$ sodium acetate $/ 9 \%$ acetic acid, washed with water, and added with $0.025 \mathrm{~N} \mathrm{NaCl}$. The optical density of each sample was measured at $575 \mathrm{~nm}$.

\section{Statistical analysis}

All data are presented as means \pm SD for the indicated number of observations. Data were analysed by Student's $t$-test for unpaired data. Differences were considered significant at $p$ less than 0.05 . 


\section{Results}

No expression of Fas mRNA was detected by RTPCR in primary cultured mouse islet cells. To examine the possible effect of IL-1 $\alpha$ on Fas mRNA expression, islet cells were incubated with IL- $1 \alpha$ at concentrations of $10^{2}, 10^{3}, 10^{4}$, or $10^{5} \mathrm{U} / \mathrm{l}$ for up to $12 \mathrm{~h}$ (Fig.1). Although the cells were still negative for Fas mRNA after 1-h incubation, 4-h exposure to IL-1 $\alpha$ at any dose used here resulted in the induction of Fas mRNA. Fas mRNA was also detectable at $12 \mathrm{~h}$. Whereas a sequence of $287 \mathrm{bp}$ of $\beta$-actin cDNA was amplified from all the samples. This experiment was performed three times with essentially the same result. To confirm that the RT-PCR of Fas amplified relevant sequence, the 424-bp PCR products were cloned and sequenced bidirectionally. The nucleotide sequence was completely identical with bases 45-468 of the previously published sequence of mouse Fas cDNA [20].

The capacity of IL-1 $\alpha$ to induce cell surface Fas expression was then tested. Primary cultured dispersed islet cells incubated with or without IL-1 $\alpha$ for 6 or $12 \mathrm{~h}$ were stained with non-cytolytic anti-Fas antibody (RMF6) and analysed by immunofluorescence and flow cytometry. Figure 2 shows that the exposure of islet cells to $10^{3} \mathrm{U} / \mathrm{l}$ of IL- $1 \alpha$ resulted in the surface expression of Fas molecules. At $12 \mathrm{~h}$, the peaks of relative fluorescence intensity of cells incubated without and with IL- $1 \alpha$ were 58 and 75, respectively. Whereas, the IL-1-induced shift of peaks was not obtained when rat $\mathrm{IgG}$ was used as a control.

To assess whether islet cell surface Fas can transduce death signal, IL-1 $\alpha$-treated cells were exposed to agonistic anti-Fas antibody (RK8). Figure 3 shows the time course of islet cell lysis evaluated by the ${ }^{51} \mathrm{Cr}$-release assay. Spontaneous ${ }^{51} \mathrm{Cr}$ release at 24 , 48 , and $72 \mathrm{~h}$ was 14,25 , and $33 \%$, respectively. The lysis of IL- $1 \alpha$-pretreated cells was observed $24 \mathrm{~h}$ after the addition of anti-Fas antibody, and the specific ${ }^{51} \mathrm{Cr}$ release was progressively increased to $72 \pm 6 \%$ at $72 \mathrm{~h}$. Incubation for $48 \mathrm{~h}$ with 0.5 or $5 \mathrm{mg} / \mathrm{l}$ of antiFas antibody alone did not cause significant islet cell lysis (Fig. 4). However, islet cell damage was evoked when the cells had been treated with $10^{2}-10^{3} \mathrm{U} / \mathrm{l}$ of IL-1 $\alpha$ before exposure to anti-Fas antibody. Although IL-1 is cytotoxic to islet cells at higher concentrations, islet cell lysis was not caused by $10^{2}-10^{3} \mathrm{U} / \mathrm{l}$ of IL-1 $\alpha$ alone.

To exclude the possibility that islet cell lysis was mediated by TNF receptors with which anti-Fas antibody might cross-react, we examined the effect of anti-Fas RK8 on TNF-sensitive L929 cells. Exposure of the cells to TNF- $\alpha$ for $18 \mathrm{~h}$ in the presence of $1 \mathrm{mg} / \mathrm{l}$ of actinomycin D resulted in cell lysis in a dose-dependent manner. However, RK8 antibody at the levels of $1-10 \mathrm{mg} / \mathrm{l}$ in combination with $1 \mathrm{mg} / \mathrm{l} \mathrm{ac}$ tinomycin D did not induce L929 cell lysis (Table 1).

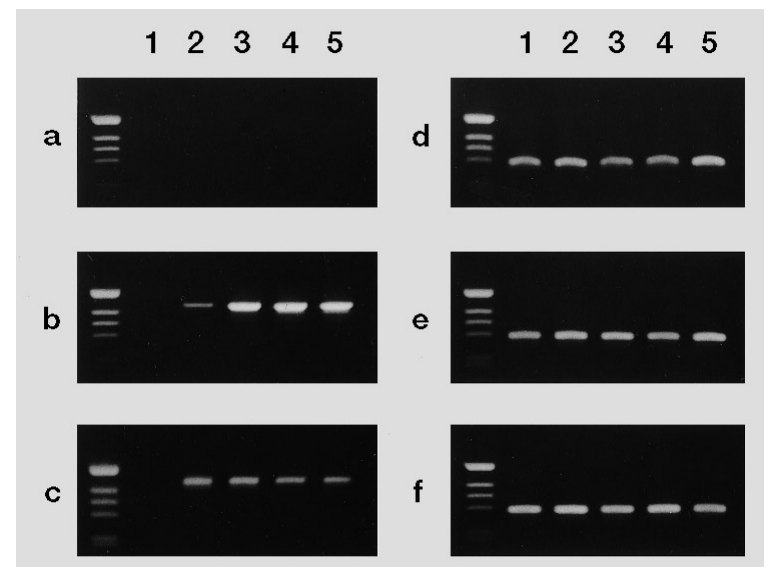

Fig. 1.a-f. IL- $1 \alpha$-induced Fas mRNA expression by mouse islet cells. Islet cells were exposed to IL-1 $\alpha$ for $1 \mathrm{~h}(\mathbf{a}, \mathbf{d}), 4 \mathrm{~h}(\mathbf{b}$, e) or $12 \mathrm{~h} \mathrm{(c,} \mathrm{f).} \mathrm{IL-1} \alpha$ concentrations were 0 (lane 1$), 10^{2} \mathrm{U} / \mathrm{l}$ (2), $10^{3} \mathrm{U} / \mathrm{l}(3), 10^{4} \mathrm{U} / \mathrm{l}$ (4) or $10^{5} \mathrm{U} / 1$ (5). Fas mRNA (a, b, c) and $\beta$-actin mRNA (d, e, f) were reverse transcribed and amplified by PCR by 35 cycles and 30 cycles, respectively. DNA molecular weight markers were 506, 396, 344, and 298 bp from top

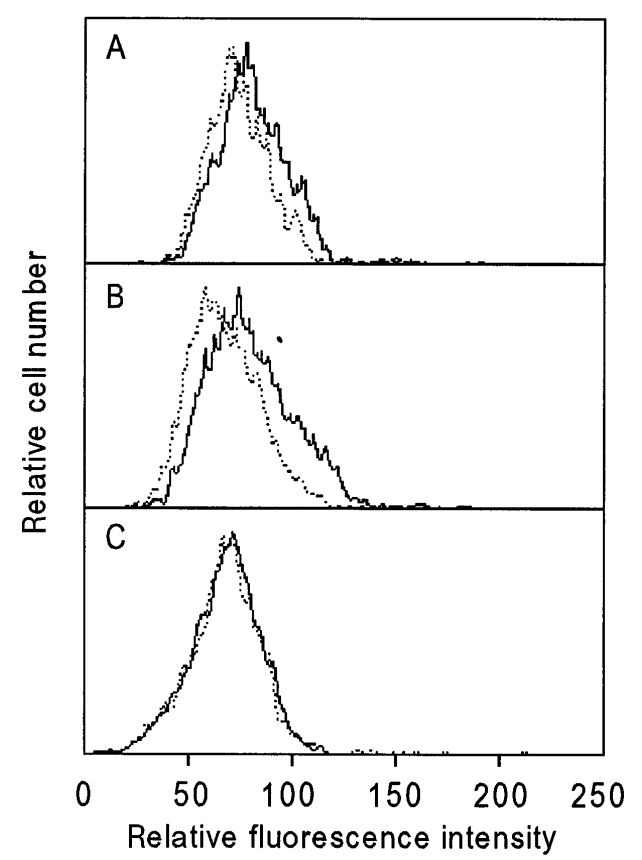

Fig. 2. A-C. Induction by IL-1 $\alpha$ of Fas expression. Mouse islet cells were cultured in the presence (solid line) or absence (broken line) of $10^{3} \mathrm{U} / \mathrm{l}$ of IL- $1 \alpha$ for $6 \mathrm{~h}(\mathbf{A})$ or $12 \mathrm{~h}(\mathbf{B}, \mathbf{C})$. Then the cells were incubated with non-cytolytic rat anti-Fas monoclonal antibody (A, B) or rat IgG $(\mathbf{C})$, and stained with FITC-conjugated rabbit anti-rat $\mathrm{IgG}$. Fluorescence intensity was analysed by flow cytometry. Experiments $\mathbf{A}, \mathbf{B}$, and $\mathbf{C}$ were performed independently four times, and representative data are shown

Since protein synthesis inhibitors potentiate Fasmediated apoptosis of various cells, we examined the effect of cycloheximide on anti-Fas antibody-induced islet cell lysis. Islet cells were incubated with $5 \mathrm{mg} / \mathrm{l}$ of anti-Fas antibody (RK8) after 12-h pretreatment with 


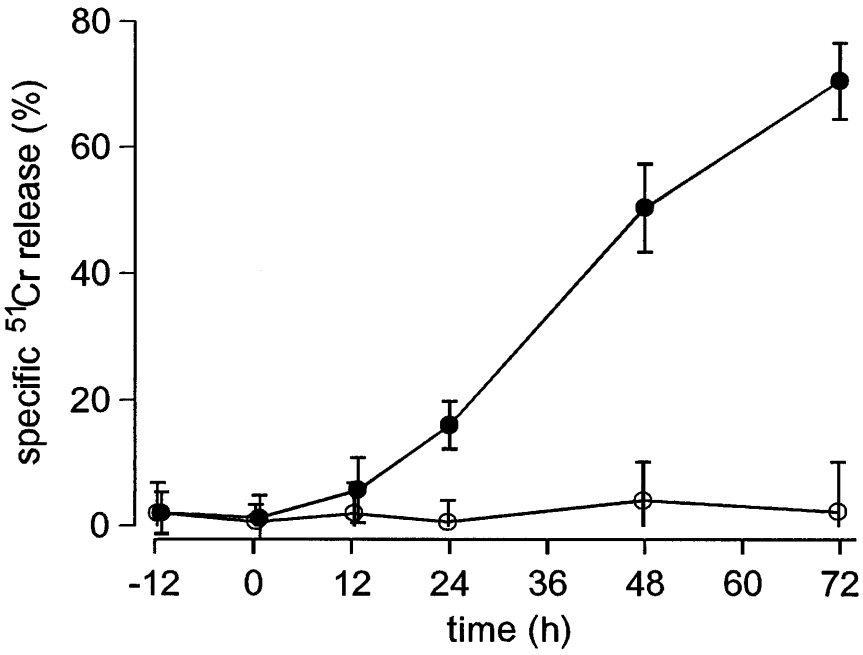

Fig. 3. Islet cell destruction induced by IL-1 $\alpha$ and anti-Fas antibody. Islet cells of $1 \times 10^{4}$ cells/well were exposed to IL- $1 \alpha$ of $10^{3} \mathrm{U} / \mathrm{l}$. After $12 \mathrm{~h}$ agonistic anti-Fas monoclonal antibody (RK8) was added to the cultures at the concentration of $5 \mathrm{mg} / \mathrm{l}$. Cell lysis was evaluated by the ${ }^{51} \mathrm{Cr}$-release assay. Specific ${ }^{51} \mathrm{Cr}$ release $=100 \times($ test $\mathrm{cpm}-$ spontaneous $\mathrm{cpm}) /($ total $\mathrm{cpm}-$ spontaneous cpm). $\bigcirc$, blank; $\bigcirc$, IL-1 $\alpha$ plus anti-Fas. Data are means $\pm \mathrm{SD}(n=4)$

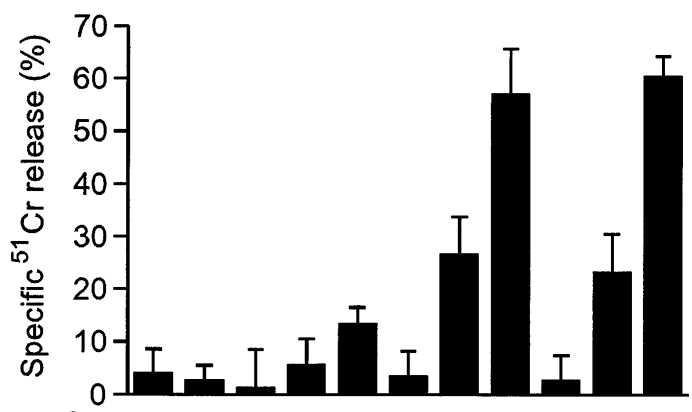

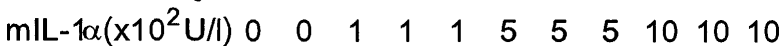

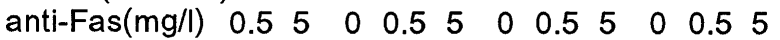

Fig. 4. Islet cell lysis induced by IL-1 $\alpha$ and anti-Fas antibody measured by the ${ }^{51} \mathrm{Cr}$ release assay. ${ }^{51} \mathrm{Cr}$-labelled mouse islet cells were incubated for $48 \mathrm{~h}$ with agonistic anti-Fas monoclonal antibody added $12 \mathrm{~h}$ after the addition of IL-1 $\alpha$. Data are means $\pm \mathrm{SD}(n=4)$

$10^{3} \mathrm{U} / 1$ of IL-1 $\alpha$. Anti-Fas-induced islet cell damage was still mild at $24 \mathrm{~h}$ without cycloheximide. The supplementation of cycloheximide together with anti-Fas antibody significantly enhanced the lysis of IL-1 $\alpha$ pretreated islet cells $(p<0.01)$. Incubation for $24 \mathrm{~h}$ with cycloheximide alone did not result in islet cell lysis (Table 2).

Although nitric oxide (NO) production from Larginine by islet cells is one of the mechanisms by which IL-1 exerts its cytotoxic effects on islet cells [23-25], 0.2 and $1 \mathrm{mmol} / \mathrm{l}$ of $\mathrm{N}^{\mathrm{G}}$-monomethyl-L-arginine (NMMA), an inhibitor of NO synthetase, did not significantly attenuate islet cell lysis induced by antiFas antibody (Table 3). Furthermore, IL-1 $\alpha$-treated
Table 1. Cytotoxicity of anti-Fas antibody (RK8) on TNF-sensitive L929 cells

\begin{tabular}{lll}
\hline Sample & & Absorbance at $575 \mathrm{~nm}$ \\
\hline Blank & & $0.855 \pm 0.024$ \\
Mouse TNF- $\alpha$ & $10 \mathrm{U} / 1$ & $0.838 \pm 0.026$ \\
& $10^{2}$ & $0.744 \pm 0.033^{\mathrm{a}}$ \\
& $10^{3}$ & $0.579 \pm 0.051^{\mathrm{a}}$ \\
RK8 & $10^{4}$ & $0.287 \pm 0.029^{\mathrm{a}}$ \\
& $1 \mathrm{mg} / \mathrm{l}$ & $0.848 \pm 0.013$ \\
& 5 & $0.862 \pm 0.043$ \\
& 10 & $0.851 \pm 0.024$ \\
\hline
\end{tabular}

L929 cells were incubated with control TNF- $\alpha$ or RK8 in the presence of $1 \mathrm{mg} / \mathrm{l}$ actinomycin $\mathrm{D}$ for $18 \mathrm{~h}$. Viability was determined by the amido black assay. Data are means $\pm \operatorname{SD}(n=6)$ ${ }^{\mathrm{a}} p<0.001$ vs blank

Table 2. Effects of IL-1 $\alpha$ pretreatment and protein synthesis inhibition on cytotoxicity of anti-Fas antibody to mouse islet cells

\begin{tabular}{lc}
\hline Treatment & Specific ${ }^{51}$ Cr release $(\%)$ \\
\hline IL-1 $\alpha\left(10^{3} \mathrm{U} / \mathrm{l}\right)$ & $2.1 \pm 3.1$ \\
Anti-Fas $(5 \mathrm{mg} / \mathrm{l})$ & $1.0 \pm 3.9$ \\
CHX $(10 \mu \mathrm{mol} / \mathrm{l})$ & $3.3 \pm 2.5$ \\
IL-1 $\alpha\left(10^{3} \mathrm{U} / \mathrm{l}\right)$ and anti-Fas $(5 \mathrm{mg} / \mathrm{l})$ & $17.7 \pm 4.5$ \\
IL-1 $\alpha\left(10^{3} \mathrm{U} / \mathrm{l}\right)$, anti-Fas $(5 \mathrm{mg} / \mathrm{l})$ & \\
and CHX $(10 \mu \mathrm{mol} / \mathrm{l})$ & $41.3 \pm 5.9^{\mathrm{a}}$ \\
\hline
\end{tabular}

Islet cell death was evaluated by the ${ }^{51} \mathrm{Cr}$ release assay $24 \mathrm{~h}$ after the addition of anti-Fas (RK8). IL-1 $\alpha$ and cycloheximide $(\mathrm{CHX})$ were supplemented $12 \mathrm{~h}$ and 10 min respectively before the addition of anti-Fas. Data are means $\pm \mathrm{SD}(n=6)$

${ }^{\mathrm{a}} p<0.001$ vs IL- $1 \alpha$ and anti-Fas

islet cells were damaged by anti-Fas antibody in the absence of $\mathrm{L}$-arginine as well as in the presence of $\mathrm{L}^{-}$ arginine in culture medium.

To assess whether anti-Fas antibody induces DNA fragmentation in IL-1 $\alpha$-treated islet cells, islet cell nuclear DNA was analysed by electrophoresis on agarose gels after 48-h incubation with agonistic antiFas antibody (RK8) following 12-h culture with $10^{3}$ U/1 of IL-1 $\alpha$. Ethydium bromide staining showed internucleosomal fragmentation of DNA, indicating that the cell lysis was apoptosis (Fig.5). No internucleosomal DNA cleavage was detected in cells incubated with either $10^{3} \mathrm{U} / 1$ of IL- $1 \alpha$ alone for $60 \mathrm{~h}$ or $5 \mathrm{mg} / \mathrm{l}$ of RK8 alone for $48 \mathrm{~h}$.

Next we analysed Fas mRNA of $\beta$-TC1 cells by RT-PCR to confirm that $\beta$-cells are capable of Fas expression. Although $\beta$-TC1 cells did not constitutively express Fas mRNA, 6-h incubation of the cells with $10^{3}$ or $10^{4} \mathrm{U} / 1$ mouse IL-1 $\alpha$ resulted in slight but apparent expression of Fas mRNA (Fig. 6). Incubation with $10^{5} \mathrm{U} / \mathrm{l}$ of IFN- $\gamma$ alone did not induce the expression of Fas mRNA. The combination of IL- $1 \alpha$ and IFN- $\gamma$, however, caused obvious Fas mRNA expression by $\beta$-TC1 cells. The augmentation of 
Table 3. Effects of NMMA and L-arginine on Fas-mediated islet cell damage

\begin{tabular}{|c|c|}
\hline Treatment & Specific ${ }^{51} \mathrm{Cr}$ release $(\%)$ \\
\hline IL-1 $\alpha\left(10^{3} \mathrm{U} / \mathrm{l}\right)$ and anti-Fas & $45.0 \pm 4.8$ \\
\hline plus NMMA $(0.2 \mathrm{mmol} / \mathrm{l})$ & $42.3 \pm 4.3$ \\
\hline plus NMMA $(1 \mathrm{mmol} / \mathrm{l})$ & $43.7 \pm 3.1$ \\
\hline minus L-arginine & $48.0 \pm 6.9$ \\
\hline
\end{tabular}

${ }^{51} \mathrm{Cr}$-labelled mouse islet cells were incubated with IL-1 $\alpha$ in the absence or presence of NMMA or L-arginine for $12 \mathrm{~h}$, followed by the addition of anti-Fas (RK8) to the medium. Islet cell death was evaluated $48 \mathrm{~h}$ after the addition of anti-Fas. Data are means $\pm \operatorname{SD}(n=4)$

IL- $1 \alpha$-induced Fas mRNA expression by IFN- $\gamma$ was observed in all of three independent experiments. However, the induction of Fas molecules was not detected by fluorescence-activated flow cytometry on $\beta$-TC1 cells treated with IL-1 $\alpha\left(10^{4} \mathrm{U} / \mathrm{l}\right)$ plus IFN- $\gamma$ $\left(10^{5} \mathrm{U} / \mathrm{l}\right)$ for $6 \mathrm{~h}$ (data not shown).

\section{Discussion}

It has been shown that Fas is constitutively expressed in the thymus, liver, heart, lung, and ovaries, but not in brain, spleen, testis, uterus and kidney [20]. Primary and viral infected hepatocytes have sensitivity to Fas-mediated apoptosis in vitro $[26,27]$ and an intraperitoneal injection of monoclonal anti-Fas into mice causes hepatic failure and death [28]. In this study we showed that mouse islet cells were negative for Fas mRNA, and resistant to the agonistic antiFas monoclonal antibody. However, the exposure of islet cells to IL- $1 \alpha$ resulted in the expression of Fas mRNA. Fluorescence flow cytometry using non-cytolytic anti-Fas monoclonal antibody showed surface Fas expression after 6- or 12-h incubation with IL$1 \alpha$. IL-1 has been implicated as an immunological effector molecule that mediates the destruction of $\beta$ cells in type 1 diabetes [29-31]. Incubation of pancreatic islets with IL-1 alone results in a time-dependent inhibition of glucose-stimulated insulin release which has been demonstrated to be dependent on the metabolism of L-arginine to NO [23-25]. Although this is the first report showing cytokine-induced Fas expression by islet cells, it has been described that IFN- $\gamma$ up-regulates Fas expression in various cell lines, and enhances the cytotoxic activity of anti-Fas antibody to the cells $[7,8,20]$.

IL-1 $\alpha$ rendered islet cells sensitive to the cell-killing activity of cytolytic anti-Fas antibody. The antiFas antibody-induced destruction of islet cells was associated with DNA fragmentation. Internucleosomal DNA cleavage, the characteristic phenomenon of

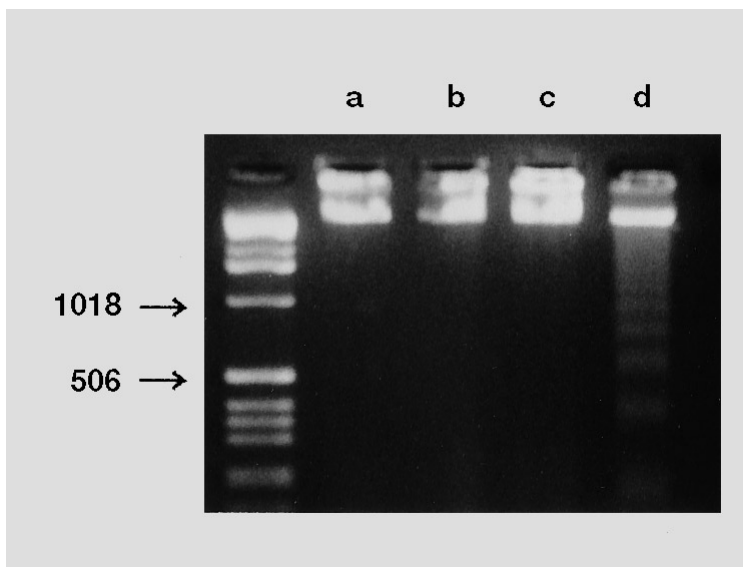

Fig. 5. Agarose gel electrophoresis of DNA from islet cells treated with IL-1 $\alpha$ and anti-Fas antibody. Primary cultured $\mathrm{Balb} / \mathrm{c}$ mouse islet cells were incubated with $10^{3} \mathrm{U} / \mathrm{l}$ of IL-1 $\alpha$ for $12 \mathrm{~h}$ and the supplemented with $5 \mathrm{mg} / \mathrm{l}$ of agonistic antiFas monoclonal antibody (RK8). After 48-h exposure, cells were lysed with proteinase K, RNase A, and sodium dodecyl sulphate. Extracted DNA samples were subjected together with $1 \mathrm{~kb}$ DNA ladder to electrophoresis. a, DNA from cells cultured without IL- $1 \alpha$ or anti-Fas; b, cells treated with IL-1 $\alpha$; c, cells treated with anti-Fas; $d$, both of IL-1 $\alpha$ and anti-Fas

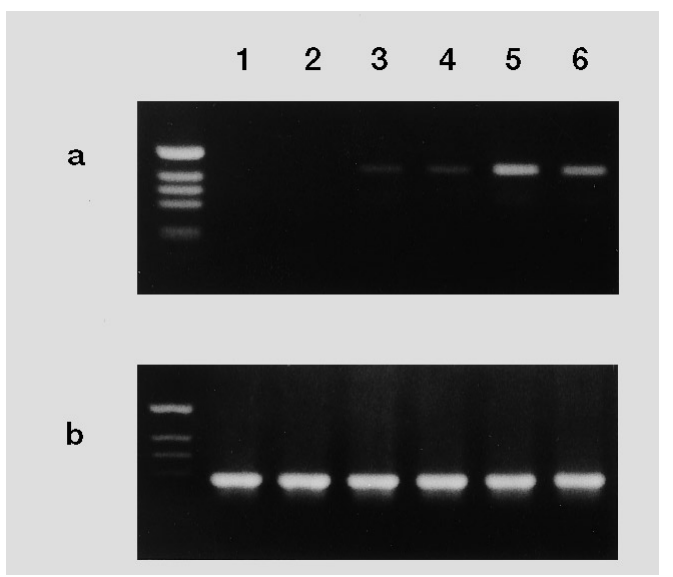

Fig. 6a, b. Cytokine-induced Fas mRNA expression by $\beta$-TC1 cells. $\beta$-TC1 cells were cultured without cytokine (lane 1 ) or exposed to $10^{5} \mathrm{U} / 1$ of IFN- $\gamma(2), 10^{3} \mathrm{U} / 1$ of IL-1 $\alpha$ (3), $10^{4} \mathrm{U} / 1$ IL-1 $\alpha$ (4), or the combination of $10^{5} \mathrm{U} / 1$ of IFN- $\gamma$ and $10^{3} \mathrm{U} / 1$ of IL- $1 \alpha$ (5) or the combination of $10^{5} \mathrm{U} / \mathrm{l}$ of IFN- $\gamma$ and $10^{4} \mathrm{U} / 1$ of IL-1 $\alpha$ (6) for $6 \mathrm{~h}$. Fas mRNA (a) and $\beta$-actin mRNA (b) were reverse transcribed and amplified by PCR by 35 cycles and 30 cycles, respectively. Representative data of three experiments are shown

apoptotic cell death, could be observed $24 \mathrm{~h}$ after the addition of anti-Fas antibody. Recently, it was reported that IL-1 itself [32-34] or a combination of IL-1, IFN- $\gamma$ and TNF- $\alpha$ [35] induces DNA damage in rat islet cells and insulinoma cell lines through NO generation. Exogenous NO also causes DNA cleavage leading to apoptosis in islet cells [34]. This study, however, showed that islet cell Fas could be induced by lower concentrations of IL- $1 \alpha$; Fas mRNA 
was induced by $10^{2} \mathrm{U} / 1$ of IL- $1 \alpha$, and Fas-based cell death and DNA fragmentation were observed when islet cells had been incubated with $10^{3} \mathrm{U} / 1$ of IL-1 $\alpha$. IL- $1 \alpha$ alone of this dose did not cause significant death or DNA fragmentation in islet cells. Furthermore, anti-Fas monoclonal antibody killed IL-1 $\alpha$ treated islet cells in the absence of L-arginine, and NMMA did not significantly protect islet cells against the antibody. Therefore, the anti-Fas antibody-induced lysis of IL- $1 \alpha$-treated islet cells is not mediated by NO generation. Previously we have shown that islet cell cytotoxicity of the combination of IFN- $\gamma$ and TNF- $\alpha$ was almost completely suppressed in the absence of L-arginine or in the presence of $0.5 \mathrm{mmol} / \mathrm{l}$ of NMMA [36]. Although Fas and TNF receptor1 have homologous intracellular death domains, death transducing signals of Fas and TNF receptor-1 are probably different. Since the anti-Fas antibody was not cytotoxic to TNF-sensitive L929 cells, the cytolytic action of the antibody on IL-1-treated islet cells cannot be attributable to possible cross reaction to TNF receptors. The relatively long period for maximum cytotoxicity may be attributable to the low density of Fas molecules on the islet cell surface. The mechanism of Fas-mediated islet cell killing requires further studies.

A protein synthesis inhibitor cycloheximide enhanced Fas-based cytolysis of various cells, such as thymocytes [37] and hepatocytes [26]. It was suggested that cycloheximide inhibits de novo synthesis of a protein which protects the cells against Fas-mediated killing. The augmentation by cycloheximide of anti-Fas antibody-induced islet cell death indicates the presence of protective mechanism requiring de novo protein synthesis. It may be the reason why it took a long time for anti-Fas antibody to kill islet cells. However, the presence of the inhibitor was not essential to Fas-mediated islet cell killing. Since antiFas antibody progressively killed IL-1-treated islet cells even in the absence of cycloheximide, the protective mechanism may be insufficient in islet cells. Unlike thymocytes and hepatocytes, the absence of constitutive Fas in islet cells may allow the incomplete protective mechanism.

Exposure to IL-1 alone or in combination with IFN- $\gamma$ induced Fas mRNA expression by $\beta$-TC1 cells, although surface Fas molecules were not detectable on cytokine-treated $\beta$-TC1 cells by immunofluorescence flow cytometry. One possible explanation for the discrepancy is that Fas expression may be downregulated by SV40 T antigens in the cells. Cytokineinduced Fas mRNA expression by $\beta$-TC1 cells suggests that beta-cells are capable of Fas expression.

If cytokines released by infiltrating cells induced Fas expression by $\beta$-cells in insulitis, islet cell surface Fas may be bound by FasL on infiltrating cells. $\mathrm{CD}^{+}{ }^{+} \mathrm{T}$ cells, the classical helper $\mathrm{T}$ subset, do not express perforin-based mechanism but express FasL and lyse in a Fas-based manner. Among the CD4 ${ }^{+} \mathrm{T}$ subpopulations, TH1 cells kill Fas-bearing cells more readily than $\mathrm{TH} 2$ cells $[38,39]$. Whereas, $\mathrm{CD}^{+}$ CTLs usually express both the Fas-based and the perforin-based mechanisms [40, 41]. Up-regulated class I major histocompatibility complex (MHC) antigens on islet cells $[1,2]$ may enhance the interaction between $\mathrm{CD} 8^{+} \mathrm{T}$ cells and islet cells. Although it is controversial whether class II MHC antigens are expressed on islet cells in insulitis, $\mathrm{CD} 4^{+}$cells could participate in Fas-based islet cell killing, because FasL may transduce death signal to Fas-bearing cells without recognition of MHC antigens [13]. Recently, it was shown that freshly isolated natural killer cells express FasL and exert Fas-based cytotoxic activity [18]. Furthermore, the soluble form of FasL released by activated lymphocytes can lyse Fas-bearing cells [42].

Our results provide the first evidence that islet cells express Fas when exposed to cytokines. Fas-mediated apoptosis may be one of the mechanisms by which $\beta$-cells are killed in autoimmune insulitis.

Acknowledgements. This work was supported in part by grantsin-aid for scientific research from the Japanese Ministry of Education, Science and Culture. We thank Dr. T. Hoshino, Department of Immunology, Kurume University, for helpful comments.

\section{References}

1. Bottazzo GF, Dean BM, McNally JM, MacKay EH, Swift PGF, Gamble DR (1985) In situ characterization of autoimmune phenomena and expression of HLA molecules in the pancreas in diabetic insulitis. $\mathrm{N}$ Engl $\mathbf{J}$ Med 313: 353-360

2. Itoh N, Hanafusa T, Miyazaki A et al. (1993) Mononuclear cell infiltration and its relation to the expression of major histocompatibility complex antigens and adhesion molecules in pancreas biopsy specimens from newly diagnosed insulin-dependent diabetes mellitus patients. J Clin Invest 92: 2313-2322

3. Dean BM, Walker R, Bone AJ, Baird JD, Cooke A (1985) Pre-diabetes in the spontaneously diabetic BB/E rat: lymphocytic subpopulations in the pancreatic infiltrate and expression of rat MHC class II molecules in endocrine cells. Diabetologia 28: 464-466

4. Miyazaki A, Hanafusa T, Yamada K et al. (1985) Predominance of $\mathrm{T}$ lymphocytes in pancreatic islets and spleen of prediabetic non-obese diabetic (NOD) mice. A longitudinal study. Clin Exp Immunol 60: 622-630

5. Trenn G, Takayama H, Sitkovsky MV (1987) Exocytosis of cytolytic granules may not be required for target cell lysis by cytotoxic T-lymphocytes. Nature 330: 72-74

6. Ostergaard HL, Kane KP, Mescher MF, Clark WR (1987) Cytotoxic T lymphocyte mediated lysis without release of serine esterase. Nature 330: 71-72

7. Yonehara S, Ishii A, Yonehara M (1989) A cell-killing monoclonal antibody (anti-Fas) to a cell surface antigen codownregulated with the receptor of tumour necrosis factor. J Exp Med 169: 1747-1756 
8. Itoh N, Yonehara S, Ishii A et al. (1991) The polypeptide encoded by the cDNA for human cell surface antigen Fas can mediate apoptosis. Cell 66: 233-243

9. Adachi M, Watanabe-Fukunaga R, Nagata S (1993) Aberrant transcription caused by the insertion of an early transposal element in an intron of the Fas antigen gene of lpr mice. Proc Natl Acad Sci USA 90: 1756-1760

10. Kobayashi S, Hirano T, Kakinuma M, Uede T (1993) Transcriptional repression and differential splicing of Fas mRNA by early transposon (ETn) insertion in autoimmune lpr mice. Biochem Biophys Res Commun 191: 617624

11. Takahashi T, Tanaka M, Brannan CI, Jenkins NA, Copeland NG, Suda T, Nagata S (1994) Generalized lymphoproliferative disease in mice, caused by a point mutation in the Fas ligand. Cell 76: 969-976

12. Ramsdell F, Seaman MS, Miller RE, Tough TW, Alderson MR, Lynch DH (1994) gld/gld mice are unable to express a functional ligand for Fas. Eur J Immunol 24: 928-933

13. Suda T, Takahashi T, Golstein P, Nagata S (1993) Molecular cloning and expression of the Fas ligand, a novel member of the tumour necrosis factor family. Cell 75: 1169-1178

14. Suda T, Nagata S (1994) Purification and characterization of the Fas-ligand that induces apoptosis. J Exp Med 179: 873-879

15. Hanabuchi S, Koyanagi M, Kawasaki A et al. (1994) Fas and its ligand in a general mechanism of T-cell-mediated cytotoxicity. Proc Natl Acad Sci USA 91: 4930-4934

16. Stalder T, Hahn S, Erb P (1994) Fas antigen is the major target molecule for $\mathrm{CD} 4^{+}$T-cell-mediated cytotoxicity. J Immunol 152: 1127-1133

17. Lowin B, Hahne M, Mattmann C, Tschopp J (1994) Cytolytic T-cell cytotoxicity is mediated through perforin and Fas lytic pathways. Nature 370: 650-652

18. Arase H, Arase N, Saito T (1995) Fas-mediated cytotoxicity by freshly isolated natural killer cells. J Exp Med 181: 1235-1238

19. Montel AH, Bochan MR, Hobbs JA, Lynch DH, Brahmi Z (1995) Fas involvement in cytotoxicity mediated by human NK cells. Cell Immunol 166: 236-246

20. Watanabe-Fukunaga R, Brannan CI, Itoh N et al. (1992) The cDNA structure, expression, and chromosomal assignment of the mouse Fas antigen. J Immunol 148: 1274-1279

21. Ni R, Tomita Y, Matsuda K, Ichihara A, Ishimura K, Ogasawara J, Nagata S (1994) Fas-mediated apoptosis in primary cultured mouse hepatocytes. Exp Cell Res 215: 332337

22. Efrat S, Linde S, Kofod H et al. (1988) $\beta$-cell line derived from transgenic mice expressing a hybrid insulin gene-oncogene. Proc Natl Acad Sci USA 85: 9037-9041

23. Welsh N, Eizirik DL, Bendtzen K, Sandler S (1991) Interleukin-1 $\beta$-induced nitric oxide production in isolated rat pancreatic islets requires gene transcription and may lead to inhibition of the Krebs cycle enzyme aconitase. Endocrinology 129: 3167-3173

24. Corbett JA, Wang JL, Sweetland MA, Lancaster Jr JR, McDaniel ML (1992) Interleukin $1 \beta$ induces the formation of nitric oxide by $\beta$-cells purified from rodent islets of Langerhans. Evidence for the $\beta$-cell as a source and site of action of nitric oxide. J Clin Invest 90: 2384-2391

25. Southern C, Schulster D, Green IC (1990) Inhibition of insulin secretion by interleukin- $1 \beta$ and tumour necrosis factor- $\alpha$ via an L-arginine-dependent nitric oxide generating mechanism. FEBS Lett 276: 42-44
26. Schultz J, Dettlaff S, Fritzsche U et al. (1994) The amido black assay: a simple and quantitative multipurpose test of adhesion, proliferative, and cytotoxicity in microplate cultures of keratinocytes (HaCaT) and other cell types growing adherently or in suspension. J Immunol Methods 167: $1-13$

27. Galle PR, Hofmann WJ, Walczak H et al. (1995) Involvement of the CD95 (APO-1/Fas) receptor and ligand in liver damage. J Exp Med 182: 1223-1230

28. Ogasawara J, Watanabe-Fukunaga R, Adachi M (1993) Lethal effect of the anti-Fas antibody in mice. Nature 364: 806-809

29. Bendtzen K, Mandrup-Poulsen T, Nerup J, Nielsen JH, Dinarello CA, Svenson M (1986) Cytotoxicity of human pI7 interleukin-1 for pancreatic islets of Langerhans. Science 232: $1545-1547$

30. Mandrup-Poulsen T, Bendtzen K, Nerup J, Dinarello CA, Svenson M, Nielsen JH (1986) Affinity-purified human interleukin I is cytotoxic to isolated islets of Langerhans. Diabetologia 29: 63-67

31. Comens PG, Wolf BA, Unanue ER, Lacy PE, McDaniel ML (1987) Interleukin 1 is potent modulator of insulin secretion from isolated rat islets of Langerhans. Diabetes 36: 963-970

32. Delaney CA, Green MH, Lowe JE, Green IC (1993) Endogenous nitric oxide induced by interleukin-1 beta in rat islets of Langerhans and HIT-T15 cells causes significant DNA damage as measured by the 'comet' assay. FEBS Lett 333: 291-295

33. Fernandez-Alvarez J, Tomas C, Casamitjana R, Gomis R (1994) Nuclear response of pancreatic islets to interleukin1 $\beta$. Mol Cell Endocrinol 103: 49-55

34. Kaneto H, Fujii J, Seo HG et al. (1995) Apoptotic cell death triggered by nitric oxide in pancreatic $\beta$-cells. Diabetes 44: 733-738

35. Rabinovitch A, Suarez-Pinzon WL, Shi Y, Morgan AR, Bleackley RC (1994) DNA fragmentation is an early event in cytokine-induced islet beta-cell destruction. Diabetologia 37: 733-738

36. Yamada K, Otabe S, Inada C, Takane N, Nonaka K (1993) Nitric oxide and nitric oxide synthase mRNA expression in mouse islet cells by interferon- $\gamma$ plus tumour necrosis factor- $\alpha$. Biochem Biophys Res Commun 197: 22-27

37. Ogasawara J, Suda T, Nagata S (1995) Selective apoptosis of $\mathrm{CD}^{+}{ }^{+} \mathrm{CD}^{+}$thymocytes by the anti-Fas antibody. $\mathrm{J}$ Exp Med 181: 485-491

38. Ramsdell F, Seaman MS, Miller RE, Picha KS, Kennedy MK, Lynch DH (1994) Differential ability of Th1 and Th2 $\mathrm{T}$ cells to express Fas ligand and to undergo activation-induced cell death. Int Immunol 6: 1545-1553

39. Ju ST, Cui H, Panka DJ, Ettinger R, Marshak-Rothstein A (1994) Participation of target Fas protein in apoptosis pathway induced by $\mathrm{CD} 4^{+} \mathrm{Th} 1$ and $\mathrm{CD}^{+}$cytotoxic $\mathrm{T}$ cells. Proc Natl Acad Sci USA 91: 4185-4189

40. Rouvier E, Luciani MF, Golstein P (1993) Fas involvement in $\mathrm{Ca}^{2+}$-independent T-cell-mediated cytotoxicity. J Exp Med 177: 195-200

41. Vignaux F, Vivier E, Malissen B, Depraetere V, Nagata S, Golstein P (1995) TCR/CD3 coupling to Fas-based cytotoxicity. J Exp Med 181: 781-786

42. Tanaka M, Suda T, Takahashi T, Nagata S (1995) Expression of the functional soluble form of human Fas ligand in activated lymphocytes. EMBO J 14: 1129-1135 